\section{Foliar Heat Tolerance of Two Hybrid Hollies}

\author{
John M. Ruter \\ Coastal Plain Experiment Station, Department of Horticulture, University of \\ Georgia, Tifton, GA 31793
}

Additional index words. electrolyte leakage, chlorophyll fluorescence, Ilex, stress physiology, temperature

\begin{abstract}
Temperatures producing heat damage in leaves of Ilex xmeserveae S.Y. Hu 'Blue Prince' and Ilex rugosa $\times$ cornuta Lindl. \& Paxt. 'Mesdob' (China Boy) were evaluated using electrolyte leakage and chlorophyll fluorescence techniques. Whole leaves were exposed to temperatures from 30 to $65 \mathrm{C}$ for 30 minutes to determine critical midpoint heat-killing temperatures (TJ using electrolyte leakage techniques. The $T_{\mathrm{m}}$ for 'Blue Prince' and 'Mesdob' was 52.4 \pm 0.1C and 53.8 $\pm 0.1 \mathrm{C}$, respectively. Dark-adapted leaves were heated for 30 minutes in darkness at temperatures between 30 and $57 \mathrm{C}$ before chlorophyll fluorescence was measured. Initial $\left(F_{0}\right)$ and peak fluorescence measurements were higher at 54 and 55C for 'Mesdob' than for 'Blue Prince'. Cultivar had no effect on variable fluorescence $(F$,$) . Based on the F_{v}: F_{0}$ ratio, 'Mesdob' was estimated to have a higher optimal plant growth temperature than 'Blue Prince'. The physiologic data support the hypothesis that $I$. cornuta as a parent conferred heat tolerance to the interspecific hybrid in this study.
\end{abstract}

Hollies ( Ilex spp.) are popular landscape plants, with $>100$ species cultivated internationally. Recently, the Meserve hybrid hollies (crosses between I. rugosa Fr Schmidt and $I$. aquifolium L.) have become popular landscape plants in the northeastern United States due to their blue-green glossy foliage and abundant production of showy fruit. High summer temperatures in conjunction with certain solar exposures have damaged the Meserve hybrids (Pair and Still, 1982). Ilex rugosa and I. aquifolium are not considered to be heat tolerant (Dirr, 1990).

The hybrid $I$. rugosa $\times$ cornuta 'Mesdob' has shown greater heat tolerance in landscape plantings than Meserve hybrids that do not have $I$. cornuta as a parent (Pair, 1987). Chinese holly ( I. cornuta) is heat and drought tolerant and may contribute heat tolerance to hybrid plants. To date, the foliar heat tolerance of certain hollies has been evaluated only under landscape situations. Physiologic data are lacking regarding the foliar heat tolerance of ornamental hollies.

Direct high-temperature injury to the plasma membrane can be estimated by conductometrically measuring electrolyte leakage from plant cells (Levitt, 1980). Direct high-temperature injury results from brief ex-

\footnotetext{
Received for publication 18 Aug. 1992. Accepted for publication 4 Dec. 1992. We appreciate the technical assistance of Bruce Tucker, statistical assistance of Ben Mullinix, and donation of plant material by Wight Nurseries. This research was funded in part by a grant from the Holly Society of America and supported by state and Hatch funds allocated to the Georgia Agricultural Experiment Station. The cost of publishing this paper was defrayed in part by the payment of page charges. Under postal regulations, this paper therefore must be hereby marked advertisement solely to indicate this fact.

Assistant Professor.
}

posure to extreme temperatures. Electrolyte leakage is an effective means of measuring cell membrane thermostability in leaf (Ahrens and Ingram, 1988; Sullivan, 1972) and holly root tissue (Ingram, 1986; Ruter and Ingram, 1991).

The plasma membrane of plant cells is more heat tolerant than photosynthetic processes (Berry and Bjorkman, 1980). The thylakoid membrane and photosystem 11 (PS II) electron transport are sensitive to high temperatures (Smillie, 1979). Measuring chlorophyll fluorescence is a simple method for studying the photosynthetic responses of plants to environmental stresses (Havaux et al., 1988; Smillie and Hetherington, 1983). The purpose of this study was to determine the foliar heat tolerance of $I$. $\times$ meserveae 'Blue Prince' and $I$. rugosa $\times$ cornuta 'Mesdob'. Determining cellular and chloroplast membrane damage is central to further understanding heat injury and tolerance in the genus Ilex.

Plants were grown in 2.8-liter containers for 5 months in a shadehouse (55\% light exclusion) under natural daylength conditions at the Coastal Plain Experiment Station in Tifton, $\mathrm{Ga}$. Daily maxima in the shadehouse ranged from 21 to $30 \mathrm{C}$ during the growing period. The potting medium consisted of 4 milled pine bark : 1 sand (v/v) amended with Micromax (Grace-Sierra, Milpitas, Calif.) at $0.9 \mathrm{~kg} \cdot \mathrm{m}^{-3}$ and Osmocote 18N-2.6P-8.8K (Grace-Sierra) applied as a topdressing at $1.5 \mathrm{~kg} \mathrm{~N} / \mathrm{m}^{3}$. Plants were watered as needed.

In Aug. 1991, electrolyte leakage procedures for determining a critical temperature for whole leaves were modified from Ahrens and Ingram (1988). Leaves (recently matured on current-season growth from four plants) were rinsed lightly with deionized water and placed in test tubes with loosely fitted screw caps. One leaf and $1 \mathrm{ml}$ of deionized water were added to each tube. Test tubes (eight samples per temperature and cultivar) were placed randomly in a thermostatically controlled water bath kept between 30 and $65 \mathrm{C}$. After 30 rein, the leaves were removed from the test tubes, cut into 5-mm strips perpendicular to the long axis of the leaf, and returned to the test tubes with $20 \mathrm{ml}$ of deionized water. Test tubes were incubated in ice for $24 \mathrm{~h}$ before determining electrical conductivity. Leaf samples were killed by autoclaving them for $20 \mathrm{~min}$ at $121 \mathrm{C}$ and $2.1 \mathrm{~kg} \cdot \mathrm{cm}^{-2}$ and placed in ice for $24 \mathrm{~h}$ before taking final electrical conductivity readings. Electrolyte leakage was expressed as the ratio of incubation solution conductivity after treatment to the conductivity after autoclaving. Critical midpoint heat-killing temperatures $\left(\mathrm{T}_{\mathrm{m}}\right)$ were determined using a model developed by Ingram (1985).

Leaves were dark-adapted for $1 \mathrm{~h}$ before applying chlorophyll fluorescence treatments. Samples were exposed to heat stress as described in the electrolyte leakage experiment, except leaves were placed for $30 \mathrm{~min}$ in the water bath at 30 to $57 \mathrm{C}$. Leaves remained in darkness during the 30-min water bath for a cumulative 1.5 -h dark period. Fluorescence was measured on whole leaves immediately after removing the test tubes from the water bath with a plant productivity fluorometer (model SF-30; Richard Brancker Research, Ottawa, Ont., Canada) calibrated at 18 $\mu \mathrm{mol} \cdot \mathrm{m}^{-2} \cdot \mathrm{s}^{-1}$ with alight meter (model LI-189; LI-COR, Lincoln, Neb.). The fluorometer's sensor head was held against the upper surface of the leaf to the left of the midrib equidistant between the apex and the petiole. Initial $\left(\mathrm{F}_{\mathrm{o}}\right)$ and peak $\left(\mathrm{F}_{\mathrm{p}}\right)$ fluorescence transient values were recorded according to the chlorophyll induction curve described by Papageorgiou (1975). Terminal fluorescence was determined $20 \mathrm{sec}$ after $\mathrm{F}_{0}$. Variable fluorescence $\left(\mathrm{F}_{\mathrm{v}}\right)$ was calculated by subtracting $\mathrm{F}_{\mathrm{o}}$ from $\mathrm{F}_{\mathrm{p}}$. Data for both experiments were analyzed using SAS software (SAS Institute, Cary, N.C.).

The foliar $\mathrm{T}_{\mathrm{m}}$ for 'Mesdob' was $\approx 1 \mathrm{C}$ higher $(53.8 \pm 0.1 \mathrm{C})$ than for'Blue Prince'(52.4 \pm $0.1 \mathrm{C})$ after a 30-min exposure to high temperatures (Fig. 1). Electrolyte leakage from leaves in this study yielded sigmoidal response curves in agreement with findings on Citrus leaves (Ahrens and Ingram, 1988). Electrolyte leakage data agreed with visual ratings, a result indicating that $I$. rugosa $\times$ cornuta hybrids were more heat tolerant than $I$. $\times$ meserveae hybrids under landscape conditions (Pair, 1987). Pair and Still (1982) noted that plant canopy temperatures occasionally exceeded $50 \mathrm{C}$ in the landscape during the summer.

$\mathrm{F}_{\mathrm{o}}$ and $\mathrm{F}_{\mathrm{P}}$ transient values were influenced significantly by cultivar $(P>\mathrm{F}=0.01)$ and temperature (Table 1). No differences between cultivars were detected for $\mathrm{F}_{\mathrm{o}}$ and $\mathrm{F}_{\mathrm{p}}$ between 30 and 52C. For each $F_{o}$ and $F_{p}$ transient value, 'Mesdob' had higher chlorophyll fluorescence at 54 and 55C than 'Blue Prince', a result that indicated functional electron transfer from PS II in 'Mesdob' at slightly higher temperatures. Due to the cubic response ( $P>\mathrm{F}=0.01)$ of both cultivars to increasing temperatures for $\mathrm{F}_{\mathrm{o}}$ and $\mathrm{F}_{\mathrm{p}}$, I could not determine a $\mathrm{T}_{\mathrm{m}}$ for 


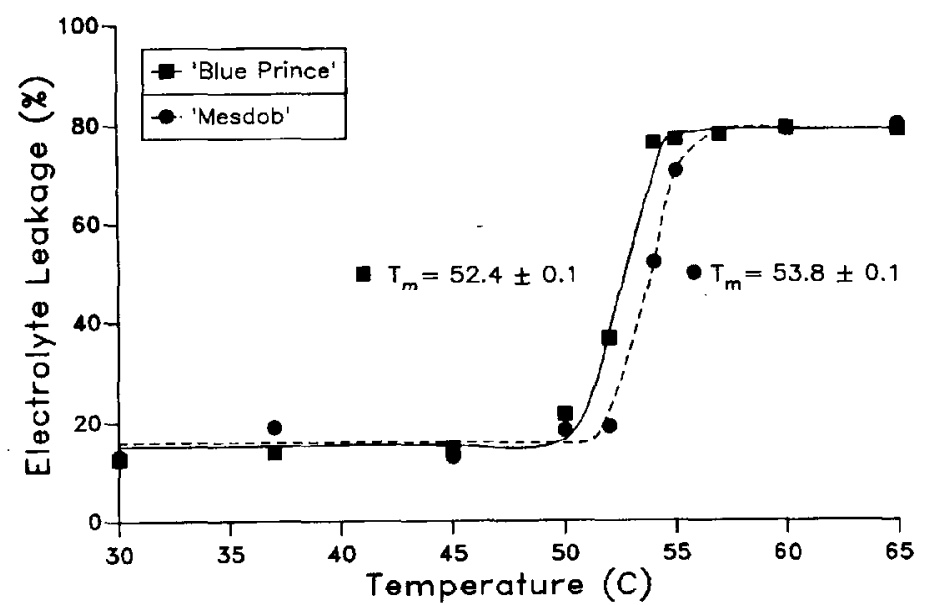

Fig. 1. Electrolyte leakage from whole leaves $(\mathrm{n}=8)$ of Ilex $\times$ meserveae 'Blue Prince' $(\square)$ and $I$. rugosa $\times$ cornuta 'Mesdob' $(\mathbf{)})$. The critical midpoint heat-killing temperature $\left(\mathrm{T}_{\mathrm{m}} \pm \mathrm{SE}\right)$ for 'Blue Prince' and 'Mesdob' was $52.4 \pm 0.1 \mathrm{C}$ and $53.8 \pm 0.1 \mathrm{C}$, respectively. Symbols used were larger than the sE for all points.

fluorescence data using Ingram's (1985) model. At the chloroplast level, the thylakoid membrane and PS II are particularly sensitive to high temperatures, and heat damage can alter the amount of measurable chlorophyll fluorescence (Berry and Bjorkman, 1980). I interpret the loss of chlorophyll fluorescence (after 30 rein) for the measured $F_{o}$ and $F_{p}$ transient values at temperatures $>52 \mathrm{C}$ to reflect direct heat damage to the chloroplast thylakoid membranes. Bilger et al. (1984) suggested that heat-induced changes in the thylakoid membrane may be connected to irreversible leaf tissue damage that occurs following exposure to high temperature. The range of temperatures at which differences in chlorophyll fluorescence $\left(\mathrm{F}_{\mathrm{o}}\right.$ and $\left.\mathrm{F}_{\mathrm{p}}\right)$ between cultivars were evident was similar to the predicted $\mathrm{T}_{\mathrm{m}}$ for each cultivar (Fig. 1). The $\mathrm{T}_{\mathrm{m}}$ for a species is the temperature that causes plasma membrane damage and cell death (Ingram and Buchanan, 1984).

$\mathrm{F}$, has been suggested as a screening test for heat tolerance because it indicates the capacity of electrons to move through PS II (Smillie and Gibbons, 1981). Changes in $\mathrm{F}_{v}$ across treatment temperatures from 30 to $52 \mathrm{C}$ resulted from a decrease in $F_{p}$, with little change occurring in $F_{0}$. A large decrease in $F_{v}$ for both cultivars occurred between 45 and 50C. Cultivar had no effect $(P>\mathrm{F}=0.24)$ on $\mathrm{F}_{\mathrm{v}}$ (Table 1).
Changes in chlorophyll fluorescence, as indicated by differences in maximal $F_{v}: F_{o}$ ratios, have been used to predict optimal plant growth temperatures (Burke, 1990; Ferguson and Burke, 1991). Cultivar $(P>\mathrm{F}=0.02)$ and temperature $(P>\mathrm{F}=0.01)$ significantly influenced the $\mathrm{F}_{\mathrm{v}}: \mathrm{F}_{\mathrm{o}}$ ratio in this study (Table 1). Between 30 and 37C, 'Blue Prince' showed no difference in $F_{v}: F_{o}$, while 'Mesdob' showed an increase, a result suggesting a higher plant growth temperature optimum for 'Mesdob'. There was no difference between cultivars at $45 \mathrm{C}$, while temperatures $>45 \mathrm{C}$ resulted in large reductions of the $\mathrm{F}_{v}: \mathrm{F}_{\mathrm{o}}$ ratios. Although the method used for determining the $F_{v}: F_{o}$ ratio in this study is not identical to that of Burke (1990), the results suggest that the $F_{v}$ : $\mathrm{F}_{\mathrm{o}}$ ratio likely would be useful for identifying optimal growth temperatures for woody plants.

Results of this study indicate that a hybrid holly ('Mesdob'), with I. cornuta as one of the parents, tolerated $\approx 1 \mathrm{C}$ more heat than a Meserve hybrid ('Blue Prince') when direct high-temperature injury to the plasma membrane was used as a test. Chlorophyll fluorescence measurements indicated that photosynthetic electron transfer in 'Mesdob' tolerated 2 to $3 \mathrm{C}$ more heat than 'Blue Prince' when $F_{o}$ and $F_{p}$ transient values were compared. Leaves can tolerate $10 \mathrm{C}$ higher temperatures, as assessed by electrolyte leakage, without heat injury than can chloroplast functions (Berry and
Bjorkman, 1980). Based on the $F_{v}: F_{o}$ ratio, optimal photosynthesis for both cultivars decreased between 37 and $45 \mathrm{C}$, with a sharp decrease between 45 and 50C. This result agrees with previous findings that the plasma membrane of plant cells is more heat tolerant than photosynthetic processes occurring in the chloroplast (Berry and Bjorkman, 1980). While electrolyte leakage is considered the standard method of assessing heat tolerance in plants (Levitt, 1980), the method used for determining the $\mathrm{F}_{v}: \mathrm{F}_{0}$ ratio in this study was useful for estimating differences in heat tolerance between cultivars at the chloroplast level. Further research using the fluorescence procedures of Burke (1990) may provide a quicker test for assessing heat tolerance and optimal growth temperatures in woody plants.

\section{Literature Cited}

Ahrens, M.J. and D.L. Ingram. 1988. Heat tolerance of citrus leaves. HortScience 24:747-748.

Berry, J.A. and O. Bjorkman. 1980. Photosynthetic response and adaptation to temperature in higher plants. Annu. Rev. Plant Physiol. 31:491-543.

Bilger, H.W., U. Schreiber, and O.L. Lange. 1984. Determination of leaf heat resistance: Comparative investigation of chlorophyll fluorescence changes and tissue necrosis methods. Oecologia 63:256-262.

Burke, J.J. 1990. Variation among species in the temperature dependence of the reappearance of variable fluorescence following illumination. Plant Physiol. 93:6524-656.

Dirr, M.A. 1990. Manual of woody landscape plants. Stipes Publishing Co., Champaign, Ill

Ferguson, D.L. and J.J. Burke. 1991. Influence of water and temperature stress on the temperature dependence of the reappearance of variable fluorescence following illumination. Plant Physiol. 97:188-192.

Havaux, M., M. Ernez, and R. Lannoye. 1988. Correlation between heat tolerance and drought tolerance in cereals demonstrated by rapid chlorophyll fluorescence techniques. J. Plant Physiol. 133:555-560.

Ingram, D.L. 1985. Modeling high temperature and exposure time interactions on Pittosporum tobira root cell membrane thermostability. J. Amer. Soc. Hort. Sci. 110:470-473.

Ingram, D.L. 1986. Root cell membrane heat tolerance of two dwarf hollies. J. Amer. Soc. Hort. Sci. 111:270-272.

Ingram, D.L. and D.W. Buchanan. 1984. Lethal high temperatures for roots of three citrus rootstock. J. Amer. Soc. Hort. Sci. 109: 189193.

Levitt, J. 1980. Response of plants to environmental

Table 1. Chlorophyll fluorescence measurements (relative units) on whole-leaf samples ( $\mathrm{n}=8)$ for 'Blue Prince' and 'Mesdob' hybrid holly after 30 min of exposure to 30 to $57 \mathrm{C} .^{\mathrm{z}}$

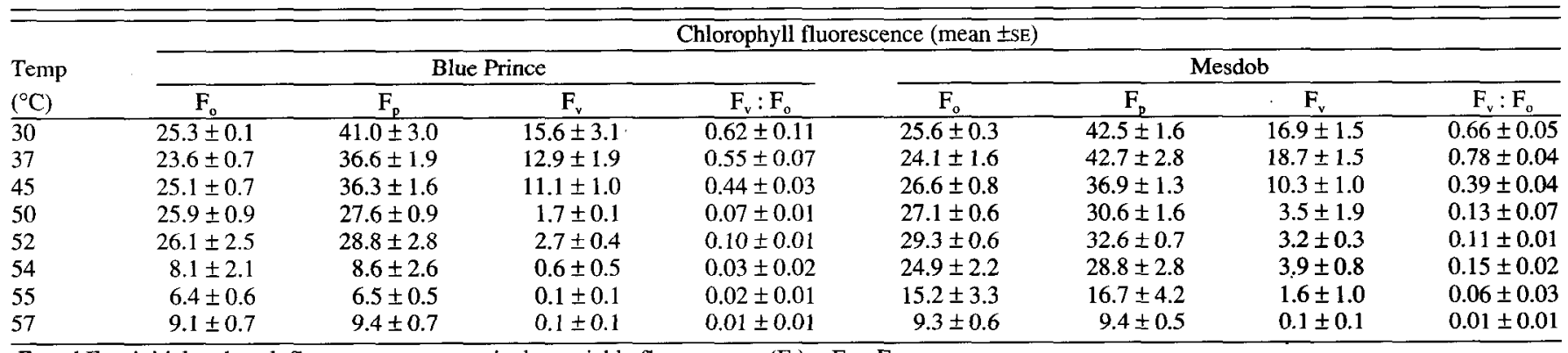

${ }^{2} F_{\mathrm{o}}$ and $\mathrm{F}_{\mathrm{p}}=$ initial and peak fluorescence, respectively; variable fluorescence $\left(\mathrm{F}_{\mathrm{v}}\right)=\mathrm{F}_{\mathrm{p}}-\mathrm{F}_{\mathrm{o}}$. 
stresses. vol. 1. Chilling, freezing and high temperature stresses. Academic, New York.

Pair, J.C. 1987. Winter hardiness, leaf water potential, and heat tolerance of 'China Girl' holly as affected by landscape exposure. HortScience 22:268-270.

Pair, J.C. and S.M. Still. 1982. Growth, hardiness, and leaf water potential of blue holly (Ilex xmeserveae) cultivars affected by exposure. HortScience 17:823-825.

Papageorgiou, G. 1975. Chlorophyll fluorescence: An intrinsic probe of photosynthesis, p. 319-
371. In: Govindjee (ed.). Bioenergetics of photosynthesis. Academic, New York.

Ruter, J.M. and D.L. Ingram. 1991. The effect of supraoptimal temperatures on root respiratory characteristics of 'Rotundifolia' holly. J. Amer. Soc. Hort. Sci. 116:560-564.

Smillie, R.M. 1979. Coloured components of chloroplast membranes as intrinsic membrane probes for monitoring the development of heat injury in intact tissues. Austral. J. Plant Physiol. 6:121133.

Smillie, R.M. and G.C. Gibbons. 1981. Heat toler- ance and heat hardening in crop plants measured by chlorophyll fluorescence. Carlsberg Res. Commun. 46:395-403.

Smillie, R.M. and S.E. Hetherington. 1983. Stress tolerance and stress-induced injury in crop plants measured by chlorophyll fluorescence in vivo. Plant Physiol. 72:1043-1050.

Sullivan, C.Y. 1972. Mechanisms of heat and drought resistance in grain sorghum and methods of measurement, p. 247-264. In: N.G.P. Rao and L.R. House (eds.). Sorghum in the seventies. Oxford \& I.B.H. Publishing, New Delhi, India. 